\title{
Perancangan Mekanik Pulmonary Rehabilitation Robot sebagai Pendukung Mekanisme Rehabilitasi Asma Breathing Retraining
}

\author{
Rasyida Shabihah Zukro Aini, Achmad Arifin, dan Atar Fuady Babgei \\ Departemen Teknik Biomedik, Institut Teknologi Sepuluh Nopember (ITS) \\ e-mail: arifin@bme.its.ac.id
}

\begin{abstract}
Abstrak-Penyakit asma merupakan proses inflamasi pada saluran pernapasan yang menyebabkan saluran pernapasan menjadi hyperresponsive sehingga mudah terjadi pembatasan aliran udara. Penanganan penyakit asma membutuhkan fokus jangka panjang sehingga membutuhkan rehabilitasi. Rehabilitasi asma pada umumnya melibatkan beban anggota tubuh pada saat pelatihan. Breathing retraining merupakan mekanisme rehabilitasi yang tepat. Untuk membantu pendertita asma bertahan dengan mekanisme tersebut sesuai dengan waktu pelatihan rehabilitasi yang distandarkan, maka dirancanglah mekanik platform pulmonary rehabilitation robot. Platform ini terdiri dari tiga mekanisme yakni armpit support, thoracic push dan belt. Mekanisme armpit support dan belt menggunakan one pulley intraction, sedangkan thoracic push menggunakan sistem scissor jack lift. Dibandingkan platform yang sudah ada untuk penderita COPD, platform ini memiliki keunggulan yakni penambahan mekanisme belt sebagai pendukung untuk ekspansi rongga dada saat inhalasi. Selain itu, penambahan audio melalui headphone untuk meredam suara platform yang bising menjadikan pengguna asma tidak mudah otot pernapasannya menjadi hyperresponsive.
\end{abstract}

Kata Kunci-Asma, Breathing Retraining, Mekanik Robot Rehabilitasi, One Pulley Traction, Scissor Jack Lift.

\section{PENDAHULUAN}

$\mathrm{B}$ ERDASARKAN data Organisasi Kesehatan Dunia WHO (World Health Organization) pada tahun 2014, asma menjadi penyebab kematian terbesar ke-13 di Indonesia. Secara lobal, Indonesia menempati peringkat ke20 sebagai negara dengan tingkat kematian akibat asma terbanyak. Namun, hanya 54\% yang terdiagnosis dengan hanya $29 \%$ dari populasi penderita dewasa penyakit asma yang dirawat, sisanya tidak terawat atau terawat sebagian. Mengobati penyakit asma secara efektif memerlukan penanganan jangka panjang dan fokus seumur hidup, sehingga sangat efektif apabila dapat ditangani dengan cara rehabilitasi. Rehabilitasi yang pada umumnya diterapkan adalah latihan fisik atau disebut juga pulmonary rehabilitation [1].

Sementara, dengan meninjau karakteristik penderita asma yang memiliki sifat mudah munculnya hyperresponsive [2] pada otot pernafasan saat menjalankan pulmonary rehabilitation dengan beban yang harus ditanggung, maka diperlukan sebuah sistem rehabilitasi yang bersifat automasi sehingga dapat mengurangi beban selama pelatihan fisik. Sehingga solusi yang dihasilkan berdasarkan kebutuhan akan

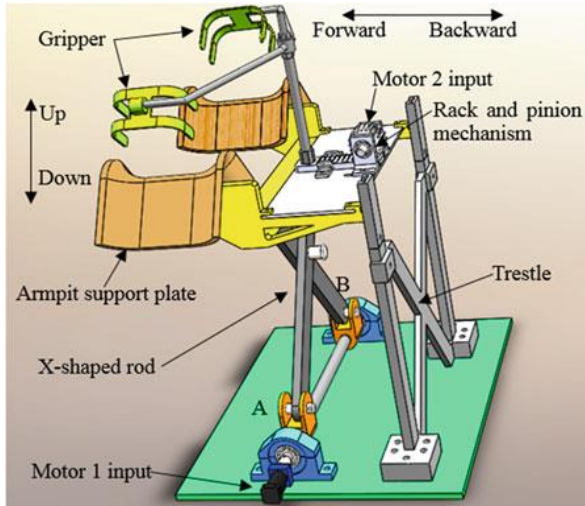

Gambar 1. Desain mekanik respiratory rehabilitation training robot untuk COPD.
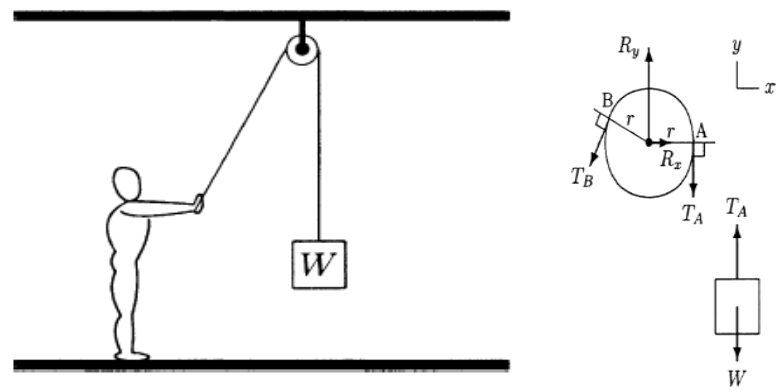

Gambar 2. Free body diagram one pulley traction.

sistem rehabilitasi tersebut, dirancanglah pulmonary rehabilitation robot sebagai pendukung mekanisme latihan terapi napas breathing retraining.

Dalam penelitian ini, perancangan pulmonary rehabilitation robot lebih menekankan pada sisi pengembangan mekaniknya. Pada awalnya, sistem mekanik platform mengadopsi sistem pada desain sebelumnya yang ditargetkan untuk penderita COPD [3]. Namun terdapat beberapa perbedaan, yakni dari pengembangan penambahan sistem dan sistem mekanik yang dirancang sendiri-sendiri. Desain mekanik platform yang diusulkan mempunyai 3 buah sistem, yaitu armpit support untuk mengangkat dan menurunkan kedua lengan, thoracic push untuk mendorong bagian thoracic, serta belt untuk menekan bagian abdomen. Ketiga sistem tersebut bergerak seiring dengan gerakan inhalasi dan ekshalasi berdasarkan breathing retraining yang dilakukan pengguna. Ketika pengguna melakukan inhalasi, armpit support bergerak naik, thoracic push bergerak maju, serta belt bergerak menekan. Sementara ketika pengguna 


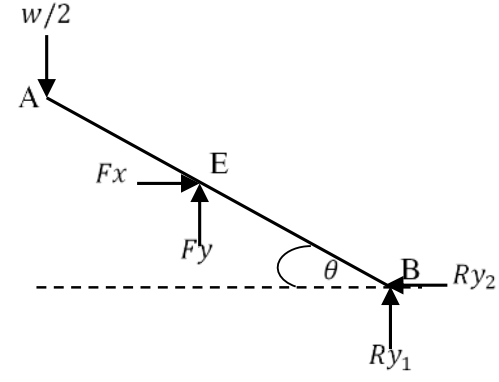

Gambar 3. Free body scissor jack lift.

melakukan ekshalasi, armpit support bergerak turun, thoracic push bergerak ke belakang dan belt melonggarkan tekanan.

\section{TINJAUAN PUSTAKA}

Sumber referensi pendukung yang digunakan dalam perancangan sistem mekanik dari pulmonary rehabilitation robot didasarkan pada platform untuk rehabilitasi COPD, mekanisme rehabilitasi asma dan adaptasi sistem mekanik.

\section{A. Pulmonary Rehabilitation Robot untuk COPD}

Pada Gambar 1, fungsi dari dua lempeng penopang melengkung yang terbuat dari karet diletakkan di bawah ketiak pasien untuk menopang berat badan bagian atas pasien saat latihan pernapasan, yang membantu pasien mengangkat dan meletakkan dadanya ke arah vertikal.

Di bagian bawah robot, terdapat mekanisme gerakan dua ulir sekrup dengan arah rotasi berbeda di setiap sisi. Sambungan batang pendukung berbentuk $\mathrm{X}$ dengan sekrup terhubung. Pada saat batang berbentuk $X$ di bawah pelat melengkung dapat mendukung pasien dan ketika sisi A dan sisi B bergerak ke satu sama lain dengan kecepatan yang sama dan digerakkan oleh motor, pelat melengkung naik dan pasien akan diangkat, dan ketika sisi A dan B bergerak jauh dari satu sama lain, pasien turun. Gerakan robot ini meniru gerakan dada dalam arah vertikal selama proses pernapasan, yang akan meringankan beban otot pernapasan dengan mengurangi berat tubuh bagian atas ketika pasien menghirup dan menghembuskan napas.

Sementara itu, diatas pelat penyangga ketiak, dua genggaman digunakan untuk menggenggam lengan pasien. Pendorongan oleh motor, dua pegangan yang terhubung dengan mekanisme rak dan pinion yang akan bergerak maju dan mundur dengan lengan untuk memperluas volume rongga dada. Kombinasi dari gerakan robot di atas merupakan gerakan dua dimensi dari dada.

Terdapat pijakan tegak vertikal di belakang robot berisi dua rel paralel, yang memastikan robot bergerak ke arah vertikal dan meningkatkan stabilitas sistem. Robot pelatihan membantu pasien dengan gerakan dada selama pelatihan pernapasan, yang akan meningkatkan kinerja otot pernapasan.

\section{B. Breathing Retraining}

Breathing retraining adalah strategi yang digunakan dalam rehabilitasi pulmonal untuk menurunkan sesak nafas dengan cara diaphragma breathing dan push-lip breathing [4]. Pushlip breathing adalah mengeluarkan udara (ekshalasi secara lambat melalui mulut dengan bibir setengah tertutup. Selama push-lip breathing, tidak ada aliran udara pernapasan terjadi melalui hidung dan menimbulkan obstruksi terhadap aliran udara ekshalasi dan meningkatkan tahanan udara, menurunkan gradien tekanan transmural dan mempertahankan jalan nafas. Proses ini membantu menurunkan pengeluaran udara yang terjebak, sehingga dapat mengontrol ekspirasi dan mengosongkan alveoli secara maksimal.

Tujuan dari diaphragma breathing dan push-lip breathing adalah untuk membantu penderita mengontrol pola nafas, meningkatkan ventilasi udara, serta meningkatkan kekuatan otot pernapasan. Keunggulan pada mekanisme ini yaitu dapat mengurangi tingkat kegelisahan pada saat melakukan rehabilitasi apabila dibandingkan dengan rehabilitasi manual [5], hal tersebut dapat mengurangi intensitas munculnya hyperresponsive otot pernapasan.

\section{One Pulley Traction}

Pengaturan pulley-cable biasanya digunakan untuk mengangkat beban dan memiliki aplikasi dalam desain perangkat traksi yang digunakan dalam rehabilitasi pasien. Mekanisme one pulley traction digunakan dalam mengangkat beban armpit pasien rehabilitasi sebagai latihan tubuh bagian atas dan belt untuk membantu pernafasan diafragma.

Keteragan free body diagram one pulley traction pada Gambar 2 menunjukkan bahwa $r$ adalah jari-jari katrol, $O$ adalah titik di sepanjang garis tengah (poros katrol), $R_{x}$ adalah gaya reaksi pada sumbu $X, R_{y}$ adalah gaya reaksi pada sumbu $Y, T_{A}$ adalah gaya tegangan tali pada titik $A, T_{B}$ adalah gaya tegangan tali pada titik $B$, serta $W$ adalah berat beban yang diangkat.

Sementara itu, untuk perhitungan momen lengan gaya pada titik $O$ dengan mempertimbangkan keseimbangan rotasi katrol dapat diidentifikasi dari Persamaan (1) yang kemudian diturunkan pada Persamaan (2).

$$
\begin{gathered}
\sum M_{o}=r T_{B}-r T_{A}=0 \\
T_{B}=T_{A}
\end{gathered}
$$

\section{Scissor Jack Lift}

Gambar 3 menggambarkan free body diagram untuk salah satu sisi scissor jack lift yang mana digunakan untuk mekanisme thoracic push. Perhitungan torsi motor DC pada desain mekanik thoracic push dapat dilihat pada Persamaan (3) hingga Persamaan (7).

$$
\begin{gathered}
F x=m a_{x} \\
F x=m(l \operatorname{los} \theta) \\
F y=m a_{y} \\
F y=m(l \sin \theta) \\
\sum F x=F x-R x_{1} \\
\sum F y=F y+R y_{1}-\frac{w}{2} \\
\sum \tau=-2 l \cos \theta\left(\frac{w}{2}\right)+F y(l \cos \theta)+\tau_{m}=0 \\
\tau_{m}=2 l \cos \theta\left(\frac{w}{2}\right)-F y(l \cos \theta)
\end{gathered}
$$

dimana $m$ adalah massa batang sepanjang $l, a$ adalah percepatan (turunan jarak terhadap waktu), $R$ adalah gaya motor $1, w$ adalah massa beban, $F$ adalah gaya yang bekerja, $\tau$ adalah torsi yang bekerja, serta $\tau_{m}$ adalah torsi motor. 


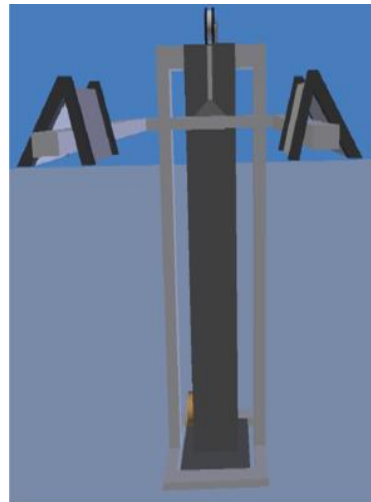

(a)

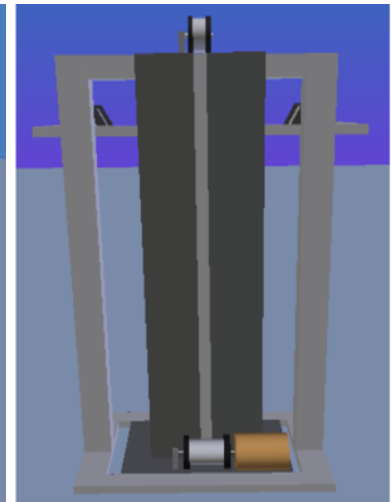

(b)

Gambar 4. Desain armpit support (a) tampak depan; (b) tampak belakang

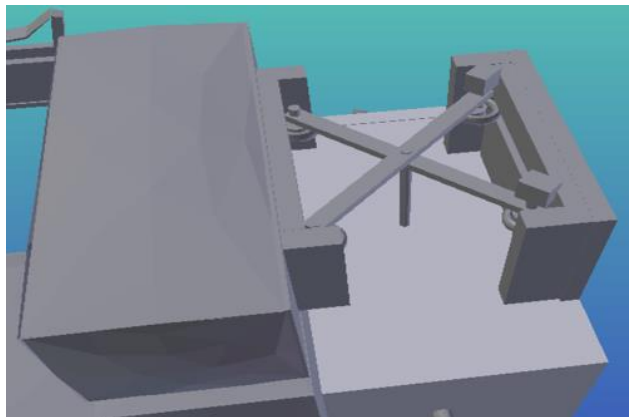

Gambar 5. Desain thoracic push

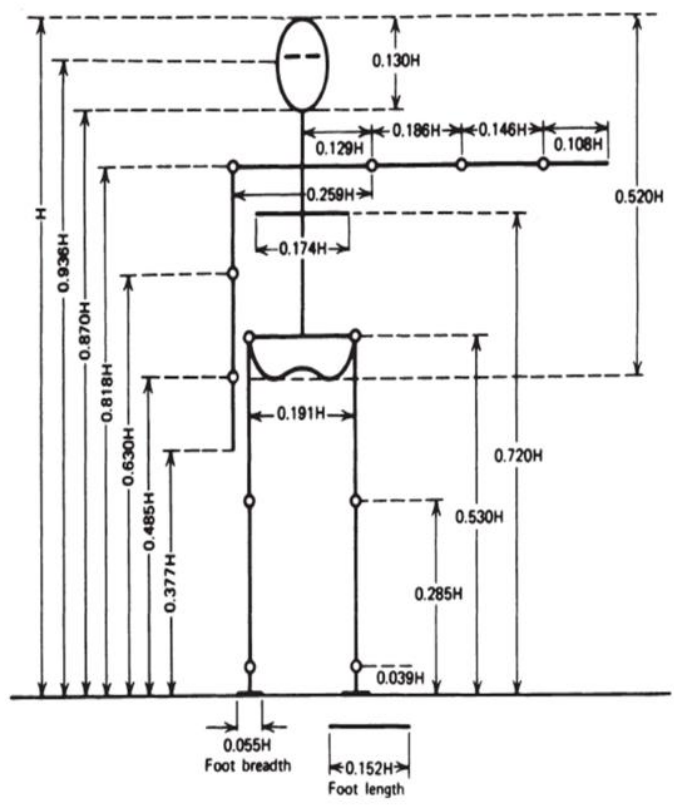

Gambar 6. Antropometry tubuh manusia

\section{PERANCANGAN ALAT}

Perancangan mekanik alat dimulai dari menentukan terlebih dahulu sistem mekanik yang akan digunakana untuk masing-masing bagian, setelah itu simulasi menggunakan software pada desain awal.

\section{A. Mekanisme Sistem Mekanik}

Bagian mekanik pulmonary rehabilitation robot yang membutuhkan perhitungan sistem mekanik adalah pada bagian armpit support, thoracic push, serta belt. Ketiga bagian tersebut merupakan effector yang langsung bersentuhan dengan subjek pengguna. Disamping itu, ketiga
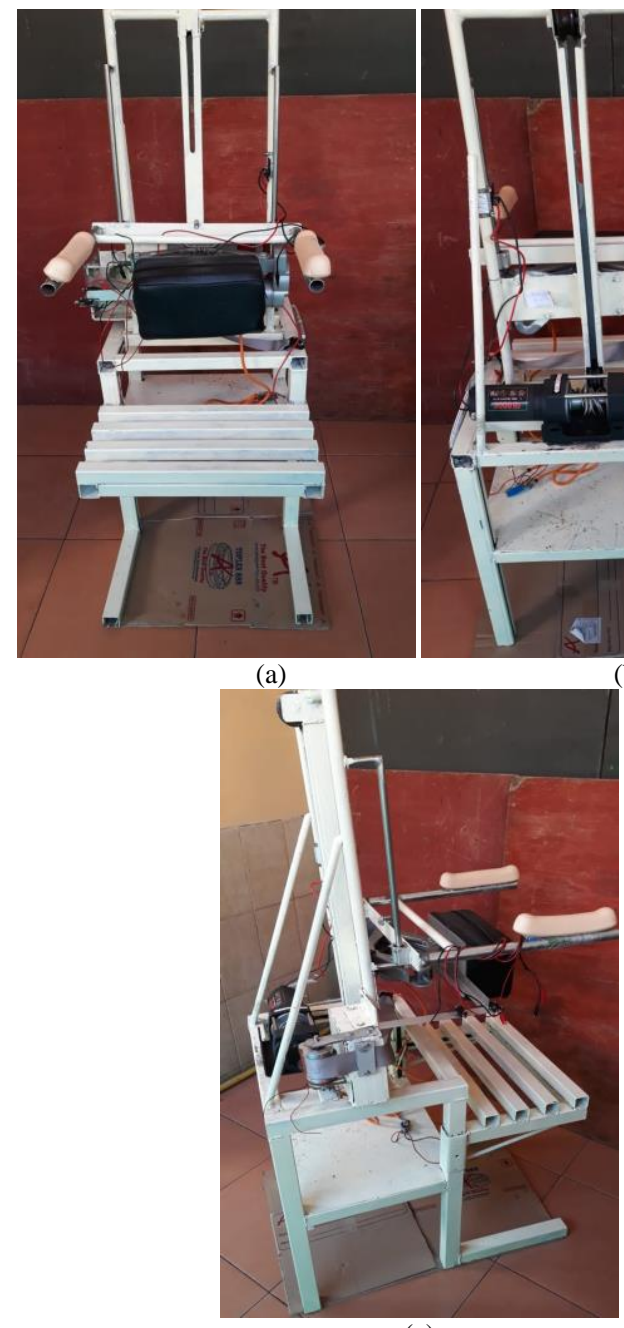

(c)

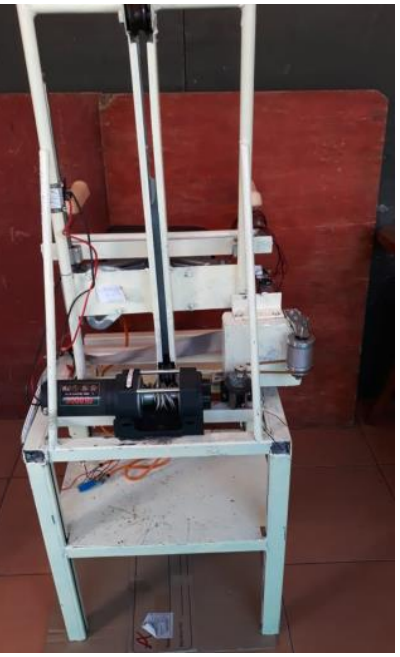

(b)
Gambar 7. Realisasi mekanik platform keseluruhan (a) tampak depan; (b) tampak belakang; (c) tampak samping

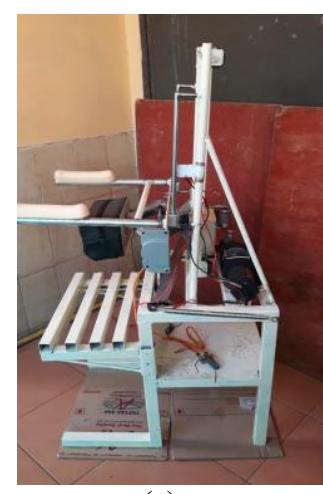

(a)

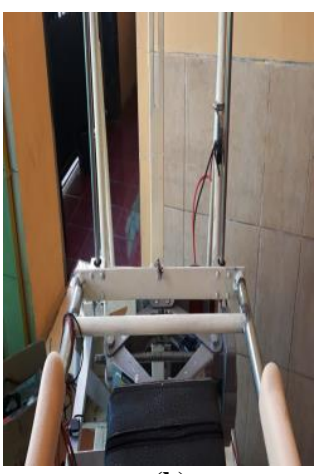

(b)
Gambar 8. Mekanik armpit support (a) tampak samping; (b) tampak depan

bagian tersebut memiliki tugas dengan jangkauan pergerakannnya masing-masing.

Armpit support menggunakan mekanisme one pulley traction, mekanisme ini dipilih karena selain mampu mengangkat beban utama yakni anggota tubuh bagian atas melalui lengan subjek, juga karena mekanismenya yang memungkinkan untuk dibuat terlebih dahulu dan tidak terintegrasi dengan yang lain.

Thoracic push menggunakan mekanisme scissor jack lift. Mekanisme ini dipilih dengan sebab pergerakan thoracic push yang ditargetkan dalam jangkauan horizontal yakni untuk menambah ruang ekspansi rongga dada saat melaksanakan inhalasi. Memanfaatkan prinsip satu tuas 


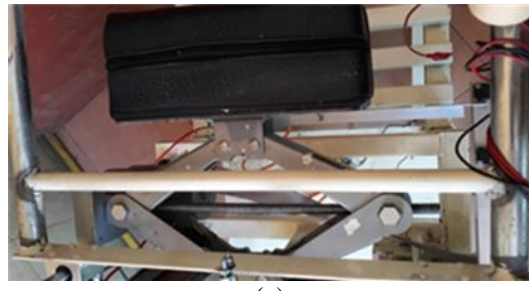

(a)

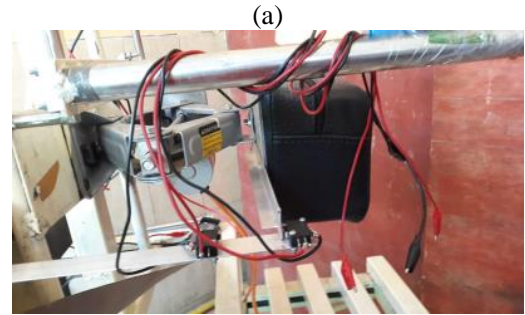

(b)

Gambar 9. Mekanik thoracic push (a) tampak atas; (b) tampak samping

Tabel 1.

Realisasi ukuran mekanik armpit support

\begin{tabular}{lc}
\hline \hline \multicolumn{1}{c}{ Bagian Mekanik } & Ukuran $(\mathrm{cm})$ \\
\hline Lebar tiang penyangga katrol & 35 \\
Lebar antar bahu & 41 \\
Bantalan armpit (panjang $x$ lebar) & $20 \times 4$ \\
Jarak effector dari tempat duduk & 30 \\
Diameter katrol motor DC & 8 \\
Jalur total linear bearing & 39 \\
Jarak perpindahan effector pada linear bearing & 13 \\
(dibatasi limit switch) &
\end{tabular}

$32.4 \times 10.5 \times 10.5$

Tabel 2.

Realisasi ukuran mekanik thoracic push

\begin{tabular}{lc}
\hline \hline \multicolumn{1}{c}{ Bagian Mekanik } & Ukuran $(\mathrm{cm})$ \\
\hline Panjang sekrup ulir & 34 \\
Bantalan thoracic push (panjang $x$ lebar $x$ tinggi) & $24 \times 11 \times 4$ \\
Dimensi scissor jack lift (panjang $x$ lebar $x$ & $40 \times 15 \times 5$ \\
tinggi) & 4.5 \\
Jarak perpindahan effector (dibatasi limit switch) & \\
\hline \hline
\end{tabular}

digerakkan dengan motor DC dan tuas lainnya menjadi titik tumpu.

Belt dirancang dengan ukuran yang tidak pasti panjangnya karena bergantung lebar tubuh subjek pengguna. Memberikan target pergerakan bagian perut yakni saat inhalasi bagian perut menekan ke dalam membantu proses ekspansi rongga dada. Belt menggunakan mekanisme one pulley traction.

\section{B. Simulasi Mekanik}

Simulasi mekanik sebagai desain awal yang dirancang ditunjukkan pada Gambar 4 dan 5. Gambar 4 adalah desain awal armpit support. Pada desain awal armpit support terdapat beberapa bagian yakni tuas effector, effector armpit, rangka armpit support, roda katrol 1, wire rope, katrol 2, motor DC. Sementara, pada desain awal thoracic push yang digunakan untuk mekanisme menegakkan bagian punggung khususnya thoracic memiliki beberapa bagian yakni effector, shaft, besi penyangga, rel roda, serta motor DC.

\section{HASIL DAN ANALISIS}

Hasil dari penelitian ini berupa realisasi pengembangan mekanik dari sumber platform yang telah ada dan desain awal yang dirancang. Untuk analisis, pengujian subjek terhadap

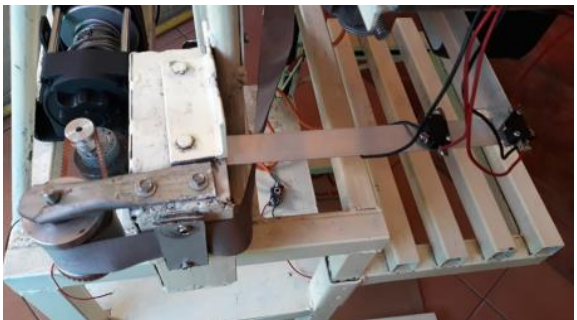

(a)
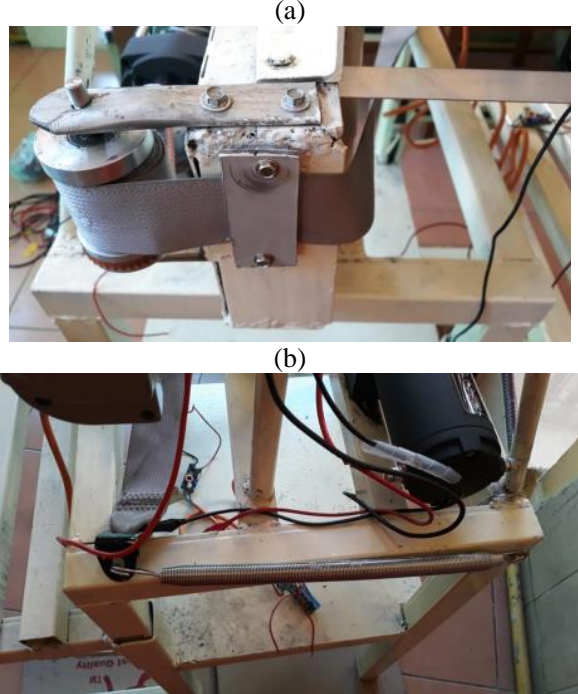

(c)

Gambar 10. Mekanik belt (a) tampak atas; (b) tampak samping; (c)peer belt

Tabel 3.

Realisasi ukuran mekanik belt

\begin{tabular}{lc}
\hline \hline \multicolumn{1}{c}{ Bagian Mekanik } & Ukuran $(\mathrm{cm})$ \\
\hline Diameter katrol effector motor & 2.5 \\
Diameter fan belt & 13.5 \\
Diameter katrol belt & 5 \\
Jarak pergerakan belt & 40 \\
Lebar belt & 4.75 \\
\hline \hline
\end{tabular}

mekanik hasil realisasi dibandingkan dengan teori anthropometry yang digunakan.

\section{A. Realisasi Mekanik}

Pengguna yang ditargetkan adalah subjek dengan usia 15 hingga 60 tahun dengan berat badan maksimal $90 \mathrm{~kg}$ dan tinggi badan berkisar antara 145 hingga $185 \mathrm{~cm}$ (tinggi badan didasarkan atas rata-rata tinggi badan Penduduk Indonesia usia dewasa yakni 165 tahun). Realisasi mekanik platform keseluruhan ditunjukkan pada Gambar 7. Hasil realisasi mekanik desain awal terbagi menjadi 5 bagian, yakni armpit support yang ditunjukkan oleh Gambar 8, thoracic push yang ditunjukkan oleh Gambar 9, belt yang ditunjukkan oleh Gambar 10, tempat duduk, serta tempat penyimpanan hardware. Sementara, realisasi ukuran mekanik didasarkan pada aturan anthropometry [6] tubuh manusia pada Gambar 6 , dimana aturan yang dipakai menurut Persamaan (8) hingga (10) :

\section{Armpit support}

a. Lebar antara bahu ke bahu : $0.259 x$ tinggi badan (8)

b. Jarak bahu dengan pinggang : $0.288 x$ tinggi badan (9)

2. Thoracic push

a. Lebar badan manusia: $0.174 x$ tinggi manusia (10)

Berdasarkan aturan anthropomentry tersebut, dihasilkan ukuran realisasi mekanik untuk armpit support, thoracic push, serta belt pada Tabel 1 hingga 3. Sementara itu untuk 
Tabel 4.

Pengujian subjek pada mekanik armpit support

\begin{tabular}{|c|c|c|c|}
\hline $\begin{array}{l}\text { Subjek } \\
\text { No-- }\end{array}$ & $\begin{array}{l}\text { Berat Badan } \\
(\mathrm{Kg})\end{array}$ & $\begin{array}{c}\text { Tinggi } \\
\text { Badan }(\mathrm{Cm})\end{array}$ & Keterangan \\
\hline 1 & 45 & 147 & $\begin{array}{l}\text { Ketiak tidak sampai tepat pada } \\
\text { effector (tidak bisa menempel } \\
\text { sama sekali) }\end{array}$ \\
\hline 2 & 85 & 158 & $\begin{array}{l}\text { Ketiak tidak sampai tepat } \\
\text { pada effector (masih bisa } \\
\text { menempel) }\end{array}$ \\
\hline 3 & 130 & 175 & $\begin{array}{l}\text { Jarak antar ketiak melebihi } \\
\text { effector }\end{array}$ \\
\hline \multicolumn{4}{|c|}{$\begin{array}{l}\text { Tabel } 5 . \\
\text { Pengujian subjek pada mekanik thoracic push }\end{array}$} \\
\hline $\begin{array}{c}\begin{array}{c}\text { Subjek } \\
\text { No- }\end{array} \\
\end{array}$ & $\begin{array}{l}\text { Berat Badan } \\
(\mathrm{Kg})\end{array}$ & $\begin{array}{l}\text { Tinggi Badan } \\
(\mathrm{Cm})\end{array}$ & Keterangan \\
\hline 1 & 45 & 147 & $\begin{array}{l}\text { Tidak nyaman, bantalan } \\
\text { terlalu tebal }\end{array}$ \\
\hline 2 & 85 & 158 & $\begin{array}{l}\text { Tidak nyaman, bantalan } \\
\text { terlalu tebal }\end{array}$ \\
\hline 3 & 130 & 175 & $\begin{array}{l}\text { Tidak nyaman, bantalan } \\
\text { terlalu tebal }\end{array}$ \\
\hline
\end{tabular}

ukuran realisasi mekanik tempat duduk dan tempat penyimpanan hardware sebagai berikut :

3. Tempat duduk
a. Range perpindahan tempat duduk $: 10 \mathrm{~cm}$
b. Panjang $x$ lebar : $50 \times 30 \mathrm{~cm}$

4. Tempat penyimpanan hardware

a. Panjang $x$ lebar $x$ tinggi : $48 \times 40 \times 25 \mathrm{~cm}$

$\mathrm{P}$ engujian Subjek terhadap Mekanik

Hasil realisasi mekanik armpit support terhadap pengguna yang ditargetkan dapat dijabarkan sebagai berikut :

1. Armpit Support

a. Berdasarkan teori pada Persamaan (8) dan (9) dihasilkan perhitungan pada tinggi subjek :

1) Lebar antar bahu ke bahu : $0.259 x$ tinggi badan

a) Pada tinggi minimum subjek : $0.259 \times 145 \mathrm{~cm}$ $=37.55 \mathrm{~cm}$

b) Pada tinggi maksimum subjek :0.259 $\times 185 \mathrm{~cm}$ $=47.91 \mathrm{~cm}$

c) Rata-rata lebar antar bahu ke bahu $: \frac{(37.55+47.915)}{2}=42.73 \mathrm{~cm}$

2) Jarak bahu dengan pinggang : $0.288 x$ tinggi badan

a) Pada tinggi minimum subjek : $0.288 \times 145 \mathrm{~cm}$ $=41.76 \mathrm{~cm}$

b) Pada tinggi maksimum subjek : $0.288 \times 185 \mathrm{~cm}$ $=53.28 \mathrm{~cm}$

c) Rata-rata jarak bahu dengan pinggang $: \frac{(41.76+53.28)}{2}=47.52 \mathrm{~cm}$

b. Berdasarkan hasil realisasi pada Tabel 1, dihasilkan ukuran platform sebagai berikut :

1) Lebar antar bahu ke bahu : $41 \mathrm{~cm}$

2) Jarak bahu dengan pinggang: $30-40 \mathrm{~cm}$

Dalam hasil perbandingan teori dan hasil realisasi tersebut diketahui bahwa dalam praktiknya, ukuran yang digunakan kurang dari rata-rata ukuran dalam teori sehingga subjek yang ditargetkan tidak dapat sesuai. Sementara itu, ukuran-ukuran lain (selain lebar antar bahu dan jarak effector dari tempat duduk) berdasarkan perkiraan, bahan mekanik yang tersedia secara umum, serta pengukuran sampel subjek secara langsung.
Sementara itu, untuk pengujian subjek terhadap mekanik armpit support pada Tabel 4 membuktikan perbandingan teori dan praktik realisasi mekanik diatas

1. Subjek dengan tinggi badan $147 \mathrm{~cm}$

: $0.259 \times 147 \mathrm{~cm}=38.073 \mathrm{~cm}$

2. Subjek dengan tinggi badan $158 \mathrm{~cm}$

: $0.259 \times 158 \mathrm{~cm}=40.922 \mathrm{~cm}$

3. Subjek dengan tinggi badan $175 \mathrm{~cm}$

: $0.259 \times 175 \mathrm{~cm}=45.325 \mathrm{~cm}$

Subjek nomor 1 dan 2 tidak dapat meletakkan armpit support tepat pada mekanik, sedangkan subjek nomor 3 melebihi mekanik armpit support baik dalam jarak lebar antar bahu maupun ukuran tubuh kebawah dikarenakan berat tubuhnya melebihi yang ditargetkan.

2. Thoracic Push

a. Berdasarkan teori sesuai dengan Persamaan (10), dihasilkan perhitungan pada tinggi subjek :

1) Lebar badan manusia : $0.174 x$ tinggi badan

a) Pada tinggi minimum subjek : $0.174 \times 145 \mathrm{~cm}$ $=25.23 \mathrm{~cm}$

b) Pada tinggi maksimum subjek : $0.174 \times 185$ $\mathrm{cm}$

$$
=32.19 \mathrm{~cm}
$$

c) Rata-rata lebar antar bahu ke bahu

$$
: \frac{(25.23+32.19)}{2}=28.71 \mathrm{~cm}
$$

b. Berdasarkan hasil realisasi, dihasilkan ukuran platform sebagai berikut :

1) Lebar badan manusia (bantalan thoracic push) : 24 $\mathrm{cm}$

Dalam hasil perbandingan teori dan praktek yang ditunjukkan pada Tabel 5. diketahui bahwa dalam prakteknya ukuran yang digunakan kurang dari rata-rata ukuran dalam teori, namun hal ini masih dapat ditoleransi oleh subjek karena bantalan yang selebar badan manusia akan menyebabkan bagian thoracic tidak nyaman. Berbeda dengan ketebalannya yang sangat mempengaruhi ruang duduk yang dijelaskan dibawah ini:

a. Sisa ruang duduk subjek (posisi minimal)

: lebar tempat duduk - (tinggi bantalan thoracic push + lebar dimensi scissor jack lift)

$: 30-(4+15)=11 \mathrm{~cm}$

b. Sisa ruang duduk subjek (posisi maksimal)

: lebar tempat duduk - (jarak perpindahan effector + lebar dimensi scissor jack lift)

$: 30-(4.5+15)=10.5 \mathrm{~cm}$

Analisis kedua kondisi diatas memperlihatkan bahwa salah perhitungan saat pembuatan realisasi tempat duduk yang jauh dari standart kursi roda yang menyebutkan rata-rata ukuran standart seat depth kursi roda adalah 16 inchi atau $40.64 \mathrm{~cm}$.

Selain kedua mekanisme tersebut, pengujian subjek terhadap mekanisme belt bergantung pada bentuk tubuh masing-masing subjek. Peer digunakan untuk menyesuaikan tubuh pengguna yang berbeda serta untuk keamanan pengguna. Untuk menghindari penderita asma menjadi lebih hyperresponsive otot pernafasannya saat pelatihan dengan platform, maka peninjauan faktor psikologis dengan menambahkan audio melalui headphone diberikan. Hal ini juga berfungsi memberikan irama bernapas yang tenang pada mekanisme breathing retraining. 


\section{KESIMPULAN}

Berdasarkan perancangan, pengujian, serta hasil telah didapatkan, dapat disimpulkan bahwa mekanisme mekanik dari platform pulmonary rehabilitation robot ini terdiri dari armpit support mengangkat armpit atau beban anggota tubuh bagian atas, thoracic push untuk mendorong bagian thoracic, serta belt untuk membantu menekan perut agar dada lebih terekspansi saat melakukan inhalasi. Selanjutnya pergerakan masing-masing mekanik akan diintegrasikan dengan fungsi yang sama pada saat inhalasi (diaphragm breathing) dan ekshalasi (push-lip breathing) dengan kecepatan lambat.

Perbedaan bentuk mekanik ini dibandingkan dengan referensi sebelumnya adalah pengguna yang ditargetkan adalah penderita asma, proses rehabilitasi dalam keadaan duduk seperti pada kursi, penambahan mekanisme belt, kecepatan konstan yang lambat dan toleransi terhadap suara motor DC dengan selanjutnya penambahan hardware headphone.

Terdapat beberapa kekurangan pada platform, yakni pada armpit support. Pada saat armpit support bergerak dari atas ke bawah saat keadaan load yang tidak lancar karena tuas effector tidak seimbang sehingga mengunci. Kekurangan pada realisasi desain mekanik thoracic push adalah bantalan thoracic yang terlalu tebal sehingga menutupi ruang untuk duduk. Serta diperlukan roda yang memiliki rem untuk mempermudah mobilitas dari platform.

Rencana penelitian lebih lanjut yang dapat dikembangkan adalah perbaikan mekanik dari platform khususnya pada mekanisme armpit support, bantalan thoracic serta mobilitas platform seperti penambahan roda.

\section{DAFTAR PUSTAKA}

[1] K. Schultz et al., "Effectiveness of pulmonary rehabilitation for patients with asthma : study protocol of a randomized controlled trial ( EPRA )," pp. 1-10, 2017, doi: 10.1186/s12890-017-0389-3.

[2] M. Kudo, Y. Ishigatsubo, and I. Aoki, "Pathology of asthma," vol. 4 no. September, pp. 1-16, 2013, doi: 10.3389/fmicb.2013.00263.

[3] Z. Zhu, T. Liu, B. Cong, and F. Liu, "Wearable Sensors and Robots,' vol. 399, 2017, doi: 10.1007/978-981-10-2404-7.

[4] U. Jurusan, T. Wicara, and P. Surakarta, "Tinjauan Pustaka Tinjauan Pustaka," J. Kesehat., no. vbbgn, pp. 1-12, 201AD.

[5] R. Laurino, V. Barnabe, B. Saraiva-Romanholo, R. Stelmach, A. Cukier, and M. Nunes, "Respiratory rehabilitation: a physiotherapy approach to the control of asthma symptoms and anxiety," Clinics, vol. 67, no. 11, pp. 1291-1297, 2012, doi: 10.6061/clinics/2012(11)12.

[6] D. A. Winter, Biomechanics and Motor Control of Human Movement, Fourth Edition David A. Winter (cloth) 1. Human mechanics. 2. Motor ability. 3. Kinesiology. I. Title. QP303.W59. 2009. 